\title{
THE CIRCULAR ECONOMY IN THE FACE OF MODERN WORLD CHALLENGES
}

\author{
HANNA PONDEL, ${ }^{1}$ IZABELA BLUDNIK ${ }^{2}$ \\ ${ }^{1}$ Poznan University of Economics and Business, Faculty of Economics, POLAND \\ e-mail: hanna.pondel@ue.poznan.pl \\ ${ }^{2}$ University of Szczecin, Faculty of Management and Economics of Services, POLAND \\ e-mail: izabela.bludnik@wzieu.pl
}

RECEIVED
ACCEPTED
JEL
CLASSIFICATION

KEYWORDS

ABSTRACT
6 November 2018

3 December 2018

O44, Q56, Q57, Q58

circular economy, sustainable development, environment policy, economic growth

Discussions on promoting economic growth in the face of environmental degradation and resource depletion more and more often refer to the concept of the circular economy (CE). Although it is still at the initial stage of its development and for the time being does not make a separate school in the structure of economic thought, it increasingly determines the way of perceiving the principles of sustainable development and the possibilities of their practical implementation. On a basis of the critical literature review, the article presents the general assumptions of the CE concept and discusses the activities undertaken in this respect in the European Union and Poland. The circular economy implementation in practice shows that it is not a perfect solution - it responds to contemporary development challenges, but its implementation limits barriers, both financial (ecodesigning and eco-innovation costs) and non-financial (legislative, public knowledge, short-term planning of activities).

\section{Introduction}

Circular economy (CE) has become extremely popular in the last few years, both among scientists and practitioners. Beside green economy and green growth, CE is seen as the most promising strategy to practically implement rules of sustainable development. After years of intense discussions, sustainable development is considered by many to be a concept too poorly defined on many levels and based on too vague assumptions to be 
fully implemented. Hence the need to develop a new model, allowing to operationalize the fundamental assumptions of sustainable development relating to society, economy and the environment. Although a dramatically growing number of studies on the subject of CE poses a risk that it may share the fate of sustainable development, for now, CE is considered to be the best way to promote economic growth in the face of pressing contemporary problems, that is environmental degradation and resource depletion (Heshmati, 2015; Kirchherr, Reike, Hekkert, 2017).

The interest in CE is growing and various stakeholders take different approaches to this model of the economy. Ecological organizations, for example, most often link this concept to the return to nature, a natural closed circulation, a situation in which every waste is utilised. However, as it was rightly noted by Krzyczkowski (2018, p. 6), it should be remembered that the concept concerns the circular economy, not the circular environment. CE is to be double "eco": ecological and economical. Much as, undoubtedly, it is environmental problems that lie at the basis of all CE-related activities, the transition to the $\mathrm{CE}$ model is to provide the economies of individual countries, regions and the world with significant savings, investment increase, innovation, and consequently - growth and economic development. It is definitely undesirable to treat circular economy and sustainable development as synonyms although the goals in both cases are convergent, the instruments to achieve these goals differ. The aim of this article is to critically review the literature in order to present general assumptions of the concept of circular economy, as well as to analyze and evaluate the activities undertaken in this area at the level of the European Union and Poland.

\section{The assumptions of circular ecconomy}

According to one of the most comprehensive CE definitions provided by Kirchherr, Reike and Hekkert (2017, p. 224-225): "A circular economy describes an economic system that is based on business models which replace the 'end-of-life' concept with reducing, alternatively reusing, recycling and recovering materials in production/ distribution and consumption processes, thus operating at the micro level (products, companies, consumers), meso level (eco-industrial parks) and macro level (city, region, nation and beyond), with the aim to accomplish sustainable development, which implies creating environmental quality, economic prosperity and social equity, to the benefit of current and future generations." $\mathrm{CE}$ is based on the $3 \mathrm{R}$ principle - reduce, reuse, recycle. Reduction refers to the minimization of energy and material inputs, which can be achieved by improving production efficiency. Reuse suggests using by-products and waste from one production stage in the next one. Finally, the recycling of used materials replaces the consumption of raw virgin materials (Heshmati, 2015, p. 2).

At the core of CE lies the idea of the economy functioning as a closed loop, which fundamentally differs from the linear economy model currently in force. Contemporary solutions are derived from mainstream economics principles, dominated by neoclassical economics, which have shaped the way of thinking about growth and economic development since the 1970s. The linear economy model is characterized by the primacy of economic goals and does not heed the problem of limited and exhaustible natural resources. As a result, it translates into a simple linear production and consumption process: extract, produce, consume, and trash, which completely (or to a large extent) ignores the problem of pollution arising at each of these stages.

The CE concept was created as a model alternative to neoclassical economics, because it gives a fundamental role to the environment, its functions and relations within it. It draws from the achievements of various theoretical positions: ecological economics, environmental economics, and industrial ecology. This concept illustrates how production and consumption can be part of a closed circuit, thereby improving the ability of present and future generations to meet their needs. In the circular economy, the $3 R$ principle aims to: optimize the consumption of all 
materials, energy, and water, cut down the consumption of raw virgin materials for the use of garbage and waste, use mainly renewable resources, reduce pollution, implement low aggregate demand and consumption.

CE aims to replace the traditional linear economy model of fast and cheap production and low-cost storage, with the production of long-lasting goods, which can be repaired or easily dismantled and recycled. The closedcircuit model is conducive to repairing, renewing and reusing products before they actually end their lives. CE strives to imitate the processes that take place in a natural environment where little is wasted and most of the waste is reused by various species of fauna and flora (Sauvé, Bernard, Sloan, 2016, p. 53).

$\mathrm{CE}$, in addition to being based on the $3 \mathrm{R}$ principle, is also based on three rules: preserve and enrich natural capital, optimize yield from resources, build system effectiveness (Growth Within..., 2015, p. 23-26). These rules can be translated into six areas of activity: Regenerate, Share, Optimize, Loop, Virtualise, Exchange - which together form the ReSOLVE ideological framework. They provide an offer of tools for companies, institutions, countries or regions to build a closed-loop strategy.

It should be clearly emphasized that CE does not create a set of views that can be distinguished in the structure of economic thought. Many authors point out that CE emerged as a result of the introduction of legal regulations (primarily in China) than the actual intellectual ferment in the scientific community (Murray, Skene, Haynes, 2017, p. 371-372).

The first countries to implement pilot projects based on the concept of CE were Japan, France, Germany and the Netherlands, but the country in which this idea is developing the most dynamically in the world and on the largest scale is China. It was introduced in 2009 using the top-down policy as a national development strategy (RaftowiczFilipkiewicz, 2015, p. 151). In contrast, in the EU, Japan or the USA, the CE concept is treated as a tool for the design of bottom-up policies regarding environmental and waste management (Ghisellini, Cialani, Ulgiati, 2016, p. 1).

\section{Implementatition of the CE concept in the European Union}

At present, $\mathrm{CE}$ is one of the most important priorities of the European Commission's economic policy and its actions are consistent with the main objectives of the $\mathrm{EU}$, including employment, economic growth, investment, climate, innovation or global efforts for sustainable development. The implementation of this concept has been announced in the circular economy package published in 2015, consisting of the communication Closing the loopAn EU action plan for the circular economy and proposals for changes to the waste directives. The Closing the loop document emphasizes the need for the introduction of changes in the following areas (Communication..., 2015):

1. Production (new perspective on design and production processes).

2. Consumption (full information, labeling, waste prevention, use of economic instruments, reduction of waste, support for innovative forms of consumption).

3. Waste management (increased targets for recycling, changes in collection and sorting systems, closing investment gap related to waste management, detection of illegal waste shipments, certification of waste treatment equipment, energy recovery).

4. Stimulation of the recycle and re-use market (the development of quality standards for secondary raw materials, the re-use of treated wastewater, the promotion of non-toxic material cycles and better traceability of potentially hazardous chemicals, facilitating cross-bordering of raw materials, stimulating demand for secondary raw materials). 
5. Priority: plastics (increased recycling, improvement of separate collection of waste, certification systems for entities collecting and sorting waste), food waste (prevention of food waste, changes in consumer behavior patterns, improvement of legal provisions), critical raw materials (high quality recycling, system of information exchange between producers and recycling plants), construction and demolition waste (increased recycling), biomass and bioproducts (growing use of renewable resources, implementation of best production practices).

As dealing with plastics was considered one of the priority areas by the EU - due to its common use in the economy and everyday life - it was given a lot of attention in the document prepared by the European Commission in January 2018 entitled A European Strategy for Plastics in a Circular Economy. The strategy adopted the main assumptions at the EU level, including increasing the market share of biodegradable plastics. As a vision of the new plastic economy, it was assumed: "A smart, innovative and sustainable plastics industry, where design and production fully respect the needs of reuse, repair, and recycling, brings growth and jobs to Europe and helps cut EU's greenhouse gas emissions and dependence on imported fossil fuels" (Communication..., 2018, p. 5).

As it appears from the Report from the Commission... (2017), as part of activities aimed at the development of $\mathrm{CE}$, the Commission has taken the following measures:

a) adopted a legislative proposal on the sale of goods via the Internet (in December 2015) - increasing guarantees for consumers, contributing to the durability of products and the possibility of repairing them, preventing the product from being thrown away;

b) adopted a legislative proposal on fertilizers (in March 2016) - favoring the creation of a single market for fertilizers produced from secondary raw materials, making the fertilizers sector independent from importing primary raw materials;

c) adopted The Ecodesign Working Plan 2016-2019 (in November 2016);

d) created the EU Platform on Food Losses and Food Waste (in 2016) - a key forum at EU level to support operators in identifying and taking action to halve the amount of food waste per capita by 2030.

Apart from the developed common position of the EU, the changes related to the introduction of $\mathrm{CE}$ require also taking into account the interests of the individual Member States of the Community. It is indispensable that this new economic model should have a comprehensive and coherent basis and be implemented at all levels - from the EU, through the Member States, to regions, provinces, and communes (Mapa drogowa..., 2018). Observing the preparations of various countries for the transition to $\mathrm{CE}$, one can notice significant differences both in the level of commitment and in the approaches to this new economic concept. In the Netherlands, as early as 2013 , a report entitled Opportunities for a circular economy in the Netherlands was drawn, and in September 2016, the CE strategy with the prospect until 2050 was adopted. Finland has also already (in 2016) adopted the CE roadmap (Krzyczkowski, 2018, p. 6).

In Poland, an initiative to develop a roadmap with proposals for national CE activities was also created. The interest in the CE model has been visible in Poland since 2016 when Interdepartmental Circular Economy Group was established by the Polish Ministry of Development. In January 2018, the Ministry of Entrepreneurship and Technology presented the project The roadmap of transformation towards a circular economy. The document contains four chapters reflecting the CE priorities, taking into account the specificity of the Polish economy. Among them are (Mapa drogowa..., 2018): 
a) sustainable industrial production - with three focus areas: industrial waste, extended producer responsibility, and environmental footprint;

b) sustainable consumption - with respect to municipal waste, food wastage, and education;

c) bioeconomy - with focus on biomass, conditions for the development of bioeconomy and bio-communes, and activities in the area of energy and industry;

d) new business models.

This map is one of the priorities of the Strategy for responsible development by 2020. The document is in the stage of interministerial and public consultations.

Poland actively participates in the creation and development of assumptions and regulations regarding CE. An example is the participation of the Ministry of Entrepreneurship and Technology in the 3-year R2 project (tRansition from linear 2 circular: Policy and Innovation), implemented as part of the Horizon 2020 program and in the Urban Agenda project in the field of supporting CE in cities.

\section{Conclusions}

Circular economy is a chance to bring together the problems of growth and development, and resource depletion. It is an alternative form of development that - with its goals and principles - fits in the emphasized for years need to manage our resources in a more sustainable manner.

Studies on CE show that many of the actions undertaken within it bring income effects, which makes this concept increasingly accepted also from the business perspective. Nevertheless, financial barriers do occur - for example, high costs associated with eco-design or eco-innovation - and hinder the transition to this new economic model. Some of the barriers hindering the transition to CE are non-financial. An example is the society's state of knowledge. According to the Stena Recycling survey conducted in 2017 on a sample of over 1,000 people, $3 / 4$ of the respondents had never heard of CE. The vast majority of Poles who have heard about CE (29\%), associate this term with environmental issues (Zamknięty obieg..., 2017).

CE is a good solution because - in principle - it takes into account the whole life cycle of the product, engages different groups of market participants in changing behaviors and implementing new models of conduct and can be implemented on various levels. Although the concept is not a perfect solution and still requires seeking better legislative models, it is undoubtedly a good direction, responding to contemporary development challenges.

The European Union is doing a lot to popularise CE, but it is necessary for the individual Member States to implement specific solutions. This concerns especially those countries that are only in the initial phase of transforming the economy into this new model of functioning. In Poland, it is necessary to switch to thinking about the long-term effects of changes and to change the perception of the implementation costs of this model. It is advisable to compare the costs of this economic transition to the costs of resigning from it.

\section{References}

Communication from the Commission to the European Parliament, the Council, the European Economic and Social Committee and the Committee of the Regions: Closing the loop - An EU action plan for the circular economy (2015). Brussels, 2.12.2015, COM (2015) 614 final. Retrieved from: https://eur-lex.europa.eu/resource.html?uri=cellar:8a8ef5e8-99a0-11e5-b3b7-01aa75ed71a1.0012.02/ DOC_1\&format=PDF. 
Communication from the Commission to the European Parliament, the Council, the European Economic and Social Committee and the Committee of the Regions: A European Strategy for Plastics in a Circular Economy (2018). Brussels, 16.1.2018, COM (2018) 28 final. Retrieved from: http://ec.europa.eu/environment/circular-economy/pdf/plastics-strategy.pdf.

Ghisellini, P., Cialani, C., Ulgiati, S. (2016). A review on circular economy: the expected transition to a balanced interplay of environmental and economic systems. Journal of Cleaner Production, 114, 11-32.

Growth Within: A Circular Economy Vision for a Competitive Europe (2015). Ellen MacArthur Foundation, Sun, McKinsey Center for Business and Environment, 16-44. Retrieved from: https://www.ellenmacarthurfoundation.org/assets/downloads/publications/ EllenMacArthurFoundation_Growth-Within_July15.pdf.

Heshmati, A. (2015). A Review of the Circular Economy and its Implementation. IZA DP, 9611. Retrieved from: http://ftp.iza.org/dp9611. pdf.

Kirchherr, J., Reike, D., Hekkert, M. (2017). Conceptualizing the circular economy: An analysis of 114 definitions. Resources, Conservation \& Recycling, 127, 221-232.

Krzyczkowski, M. (2018). Circular economy, czyli ekonomia zrównoważonego rozwoju. In: Gospodarka o obiegu zamkniętym: nowy plan dla Europy. Raport specjalny (pp. 4-6). Euractiv.pl. Retrieved from: https://pl.euractiv.eu/wp-content/uploads/sites/6/ special-report/EA-SPECIAL-REPORT-EURACTIV-PL-V01-2.pdf.

Mapa drogowa transformacji w kierunku gospodarki o obiegu zamkniętym - projekt (2018). The Ministerstwo Przedsiębiorczości i Technologii. Warszawa. Retrieved from: https://www.mpit.gov.pl/media/58665/Mapa_drogowa.pdf.

Murray, A., Skene, K., Haynes, K. (2017). The circular economy: an interdisciplinary exploration of the concept and application in a global context. Journal of Business Ethics, 140 (3), 369-380.

Raftowicz-Filipkiewicz, M. (2015). Ekonomia cyrkularna - wyzwanie i konieczność zrównoważonego rozwoju. Zeszyty Naukowe Uniwersytetu Szczecińskiego. Studia i Prace Wydziału Nauk Ekonomicznych i Zarządzania, 40 (2), 145-154.

Report from the Commission to the European Parliament, the Council, the European Economic and Social Committee and the Committee of the Regions on the implementation of the circular economy action plan (2017). Brussels, 26.1.2017, COM (2017) 33 final. Retrieved from: https://eur-lex.europa.eu/resource.html?uri=cellar:391fd22b-e3ae-11e6-ad7c-01aa75ed71a1.0001.02/ DOC_1\&format=PDF.

Sauvé, S., Bernard, S., Sloan, P. (2016). Environmental sciences: sustainable development and circular economy: alternative concepts for trans-disciplinary research. Environmental Development, 17, 48-56.

Zamknięty obieg otwiera lepsze jutro (2017). Retrieved from: https://www.stenarecycling.pl/top-menu/aktualnosci/zamknietyobieg-otwiera-lepsze-jutro.

Cite this anticle aS: Pondel, H., Bludnik, I. (2018). The circular economy in the face of modern world challenges. European Journal of Service Management, 4 (28/1), 257-262. DOI: 10.18276/ejsm.2018.28/1-32. 